\title{
Co-infusion of Autologous Adipose Tissue Derived Neuronal Differentiated Mesenchymal Stem Cells and Bone Marrow Derived Hematopoietic Stem Cells, a Viable Therapy for Post-traumatic Brachial Plexus Injury: A Case Report
}

\author{
Umang G. Thakkar' ${ }^{1}$, Aruna V. Vanikar², Hargovind L. Trivedi ${ }^{3}$
}

\begin{abstract}
Stem cell therapy is emerging as a viable approach in regenerative medicine. A 31-year-old male with brachial plexus injury had complete sensory-motor loss since 16 years with right pseudo-meningocele at C5-D1 levels and extra-spinal extension up to C7-D1, with avulsion on magnetic resonance imaging and irreversible damage. We generated adipose tissue derived neuronal differentiated mesenchymal stem cells (N-AD-MSC) and bone marrow derived hematopoietic stem cells (HSC-BM). Neuronal stem cells expressed $\beta-3$ tubulin and glial fibrillary acid protein which was confirmed on immunofluorescence. On day 14, $2.8 \mathrm{ml}$ stem cell inoculum was infused under local anesthesia in right brachial plexus sheath by brachial block technique under ultrasonography guidance with a 1.5-inch-long 23 gauge needle. Nucleated cell count was $2 \times 10^{4} / \mu 1$, CD34+ was $0.06 \%$, and CD $45-/ 90+$ and CD $45-/ 73+$ were $41.63 \%$ and $20.36 \%$, respectively. No untoward effects were noted. He has sustained recovery with re-innervation over a follow-up of 4 years documented on electromyography-nerve conduction velocity study.
\end{abstract} (Biomed J 2014;37:237-240)

\section{Key words: electromyography-nerve conduction velocity, neuronal stem cells, stem cell therapy}

$\mathrm{T}_{\mathrm{s}}^{\mathrm{s}}$ he incidence of traumatic injuries is estimated as $>500,000$ new patients annually in the world. ${ }^{[1]}$ Post-traumatic brachial plexus injury can result in complete sensory and motor function loss which is challenging for reversal of the damage, but not untreatable. Few therapeutic options like neurotization by total and hemi-contralateral nerve root transfer are available with limited benefits. ${ }^{[2]}$ Re-innervation of denervated targets can be achieved by regeneration of injured axons or by collateral branching of undamaged axons in the vicinity. Nevertheless, these mechanisms do not provide for satisfactory functional recovery, especially after severe injuries. ${ }^{[1]}$ Stem cell therapy (SCT) holds promise in tissue regeneration.

\section{CASE REPORT}

A 31-year-old man with post-traumatic brachial plexus injury since 1993 presented for SCT to our institute. He had complete loss of sensations and movements of right upper limb (UL). On examination, he had hypotonic, atrophied muscles, absent hand grip, reflex, and grade " 0 " muscle power in right shoulder-elbow-wrist joints, along with complete sensory and motor loss. He was unremarkable on general, physical, and lab evaluation. Magnetic resonance imaging showed right pseudo-meningocele at $\mathrm{C} 5$ to $\mathrm{D} 1$ levels with extra-spinal extension along the trunks of brachial plexus at C7-D1 with avulsion. Electromyography nerve conduction velocity (EMG-NCV) study revealed right brachial neuropathy-plexopathy.

From the ${ }^{1}$ Department of Stem Cell Therapy and Regenerative Medicine, G. R. Doshi and K. M. Mehta Institute of Kidney Diseases and Research Centre and Dr. H. L. Trivedi Institute of Transplantation Sciences, Civil Hospital Campus, Asarwa, Ahmedabad, Gujarat, India; ${ }^{2}$ Department of Pathology, Laboratory Medicine and Transfusion Services and Immunohematology, G. R. Doshi and K. M. Mehta Institute of Kidney Diseases and Research Centre and Dr. H. L. Trivedi Institute of Transplantation Sciences (ITS), Civil Hospital Campus, Asarwa, Ahmedabad, Gujarat, India; ${ }^{3}$ Department of Nephrology and Clinical Transplantation, G. R. Doshi and K. M. Mehta Institute of Kidney Diseases and Research Centre and Dr. H. L. Trivedi Institute of Transplantation Sciences, Civil Hospital Campus, Asarwa, Ahmedabad, Gujarat, India

Received: Jun. 12, 2013; Accepted: Mar. 03, 2014

Correspondence to: Dr. Umang G. Thakkar, Department of Stem Cell Therapy and Regenerative Medicine, G. R. Doshi and K. M. Mehta Institute of Kidney Diseases and Research Centre, Dr. H.L. Trivedi Institute of Transplantation Sciences, Civil Hospital Campus, Asarwa, India. Ahmedabad - 380 016, Gujarat, India. Tel: 91-7922687350; Fax: 91-7922685454; E-mail: umangpaedia@yahoo.co.in

DOI: $10.4103 / 2319-4170.132893$ 
We treated him with Institutional Review Board approved SCT. Adipose tissue derived mesenchymal stem cells (AD-MSC) from $10 \mathrm{~g}$ abdominal fat and hematopoietic stem cells (HSC) from $100 \mathrm{ml}$ bone marrow (BM) were generated using our previously described technique ${ }^{[3,4]}$ After trypsinization and testing for viability and sterility, the harvested mesenchymal stem cells (MSCs) were differentiated into neuronal stem cells (NSCs) using self-designed neural differentiation medium, after 4 days of isolation by concentration gradient separation medium. This inoculum was mixed with HSC generated on day 10 . No xenogeneic material was ever used. Neuronal markers like $\beta-3$ tubulin and glial fibrillary acid protein (GFAP) were confirmed on immunofluorescence staining with biotinylated mouse monoclonal IgG2A anti-neuron-specific $\beta-3$ tubulin and human GFAP affinity-purified sheep $\mathrm{IgG}$, respectively ( $\mathrm{R}$ and D system, Minneapolis, USA) [Figure $1 \mathrm{~A}$ and $\mathrm{B}$ ].

Totally $2.8 \mathrm{ml}$ of SC inoculum was infused on day 14 under local anesthesia in the right brachial plexus sheath by brachial block technique under ultrasonography (USG) guidance [Figure 1C] with a 23 gauge needle of length 1.5 inches. Nucleated cell count was $2 \times 10^{4} / \mu 1$, CD34+ was 0.06\%, and CD45-/90+ and CD45-/73+ were $41.63 \%$ and $20.36 \%$, respectively. No untoward effects of SCT were noted. There was no complication related to the technique. We never used any immunosuppression post-SCT. He was discharged after $48 \mathrm{~h}$ and advised to undergo regular physiotherapy. His pain sensations regained on dorsal and internal surface after 3 months. Gradually his finger movements developed with increase in muscle mass and sensory recovery. He had finger muscle power improved from grade 0 to grade 2 according to Kendall and

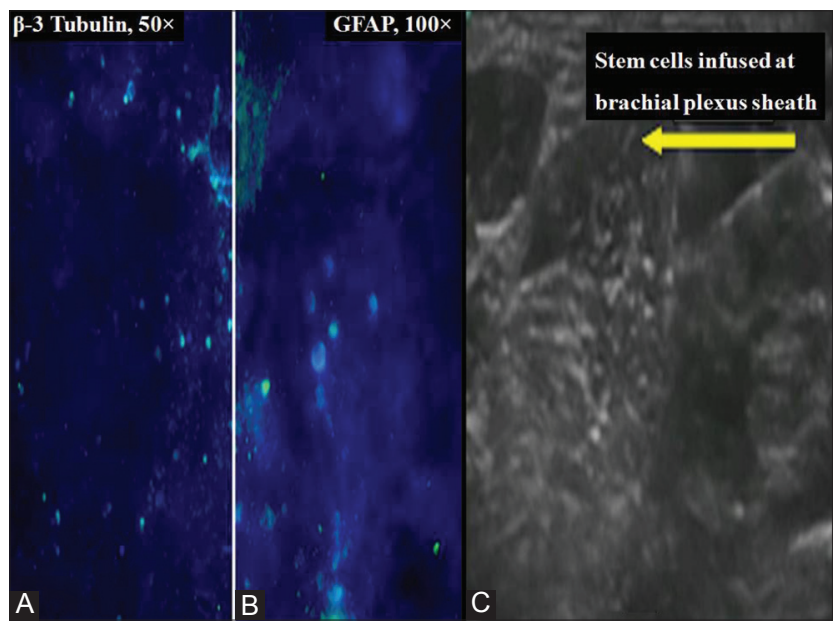

Figure 1: Photomicrographs of neuronal stem cells exhibiting (A) $\beta-3$ tubulin ( 50) and (B) glial fibrillary acid protein ( 100), by direct immunofluorescence staining using 4,6-diamidino-2-phenylindole (DAPI). (C) the technique of stem cell infusion into brachial plexus under ultrasonography guidance.
McCreary manual muscle testing [Figure 2] after 1 year. Repeat EMG-NCV revealed re-innervation in musculocutaneous, radial, axillary, and suprascapular nerves and few motor unit potentials recruiting in biceps, triceps, deltoid, and infraspinatus muscles, which has been sustained for the last 3 years.

To our knowledge, this is the first case report showing safe and effectively generated neuronal differentiated adipose tissue derived mesenchymal stem cells (N-AD-MSC) and HSC-BM without using xenogeneic material infused in the brachial plexus sheath via brachial block technique under USG guidance with a 1.5-inch-long 23 gauge needle, which led to re-innervation in musculocutaneous, radial, axillary, and suprascapular nerves and few motor unit potentials recruiting in biceps, triceps, deltoid, infraspinatus muscles on EMG-NCV study, and is a safe and viable therapy.

\section{DISCUSSION}

SCT has generated hope in the last decade for recovery from various neurological disorders/injuries. However, there are still many obstacles to be overcome before clinical application of cell therapy in neurological diseases is adopted.$^{[5]}$ Nerve regeneration often fails after injury in cases of proximal nerve injury, diffuse axonal loss, or chronic insults in peripheral nervous system. ${ }^{[6]}$

In a study, adipose tissue derived stem cells (ADSCs) isolated from inguinal adipose tissue of rat were characterized by flow cytometry, and the results showed that ADSCs were positive for MSC markers CD90 and CD44, but negative for HSC markers. ADSCs maintained self-renewing capacity and could differentiate into adipocytes and neurocytes under special culture condition. ADSCs have been shown to differentiate into neural-like cells in vitro, and have been detected by immunofluorescence with neuronal markers, GFAP and $\beta$-III tubulin. ${ }^{[7]}$

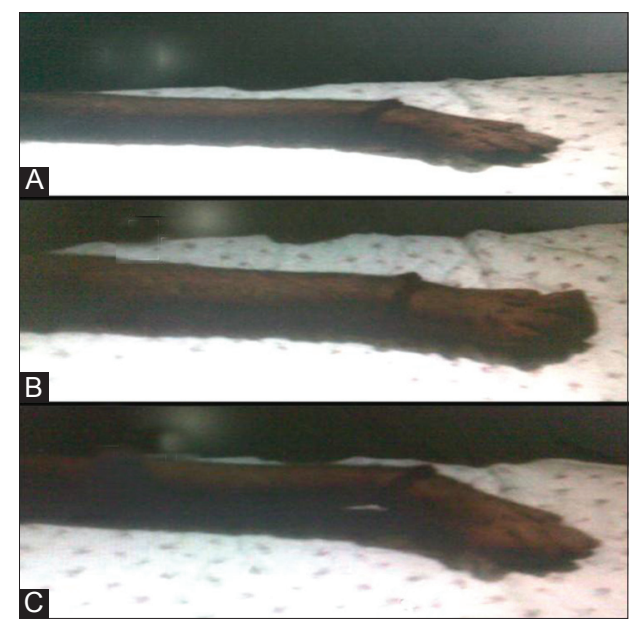

Figure 2: Image of right hand; (A-C) show functional improvement after stem cell therapy. 
SCT with local implantation of MSC in peripheral nerve injury has shown to promote nerve regeneration with axonal re-growth and myelin formation. ${ }^{[6]}$ MSCs appear to work as neurotrophic generators to promote functional recovery via angiogenesis, neurogenesis, synaptogenesis, and axonal remodeling. ${ }^{[8,9]}$ We further summarize the preclinical studies evaluating neural SCT for peripheral nerve repair in Table $1 .{ }^{[1]}$ Only a few studies have demonstrated direct evidence of cell replacement in injury or disease models, which clearly explain the benefits observed after cell therapy. Many positive outcomes after cell therapy appear to be attributed to the rescue of pre-existing tissue rather than repair or cell replacement per se. The paracrine action of growth factors, cytokines, and hormones that are secreted or released by transplanted cells has been shown to provide most of the benefits after stem/progenitor cell administration. ${ }^{[1]}$

We believe that HSC also help in angiogenesis and remodeling. Possible mechanisms for recovery are believed to be due to the neurons derived from transplanted cells relaying ascending signals disrupted by injury. Demyelinated axons are re-myelinated by transplanted cells which also have paracrine activity releasing trophic factors including brain-derived neurotrophic factors, vascular endothelial and fibroblast growth factors inducing endogenous mechanisms of tissue repair and plasticity. ${ }^{[8-13]}$ Our previous experience of combined AD-MSC and HSC infusion in the cerebrospinal fluid for treatment of traumatic paraplegia encouraged us to treat this man who had otherwise no hope of recovery from a 16-year-old injury. ${ }^{[14]}$
This report of co-infusion of autologous N-AD-MSC with HSC in brachial plexus sheath to repair and re-innervate the injured nerves and atrophied muscles opens up new avenues for treating neuromuscular injuries which were thought to be irreversible till recently.

We recommend that the therapeutic effects of SCT should be established in a more comprehensive multicenter study for this type of injury, after the results obtained in our patient.

However, the questions that remain unanswered are: Will the immune response to infused cells destroy the infused NSCs with longer time span? How much is the dose of cells required to achieve complete cure from disability? Should there be more potent or supporting cells like regulatory T-cells which will protect the infused cells and enable the recovery of injured cells?

\section{Conclusion}

We conclude that effectively generated N-AD-MSC and HSC-BM without using xenogeneic material infused in brachial plexus sheath via brachial block technique is a safe and viable therapy.

\section{Acknowledgments}

We are thankful to SD Dave and CN Patel for stem cell generation in lab and to JV Patel, BN Patel, JM Chudasma, HS Patel and PN Bhavsar for carrying out all the laboratory tests including flow cytometry analysis of this patient. We are also thankful to our librar-

Table 1: Preclinical studies evaluating stem cell therapy for peripheral nerve repair

\begin{tabular}{|c|c|c|c|}
\hline Study & Injury type/animal model & Cellular type/factor & Major findings \\
\hline Dezawa et al. (2001) & $\begin{array}{l}\text { Sciatic nerve injury in rats } \\
(1.5 \mathrm{~cm} \text { gap })\end{array}$ & $\begin{array}{l}\text { Bone marrow MSCs differentiated } \\
\text { into Schwan n-like cells suspended in } \\
\text { Matrigel injected into hollow fibers }\end{array}$ & $\begin{array}{l}\text { Successful nerve regeneration and } \\
\text { myelination }\end{array}$ \\
\hline McKenzie et al. (2006) & $\begin{array}{l}\text { Sciatic nerve crush injury } \\
\text { in myelin-deficient mice }\end{array}$ & $\begin{array}{l}\text { Skin-derived precursors differentiated } \\
\text { into Schwann cells }\end{array}$ & Remyelination and functional recovery \\
\hline Marchesi et al. (2007) & $\begin{array}{l}\text { Sciatic nerve injury in rats } \\
(1.6 \mathrm{~cm} \text { gap })\end{array}$ & $\begin{array}{l}\text { Guides filled with skin-derived stem } \\
\text { cells }\end{array}$ & Functional recovery and myelination \\
\hline Cui et al. (2008) & $\begin{array}{l}\text { Sciatic nerve injury in rats } \\
(1.0 \mathrm{~cm} \text { gap })\end{array}$ & $\begin{array}{l}\text { Mouse ES cell-derived neural } \\
\text { progenitor cells }\end{array}$ & Remyelination and functional recovery \\
\hline Lin et al. (2008) & Sciatic nerve injury in rats & Nerve conduit seeded with F1BGFP(+) & Axon regeneration \\
\hline Hsu et al. (2009a) & $(1.0 \mathrm{~cm}$ gap $)$ & Mouse neural stem cells & \\
\hline Chen et al. (2010) & $\begin{array}{l}\text { Acutely distracted sciatic } \\
\text { nerves in rabbits }\end{array}$ & Neural stem cells & Functional recovery and nerve regeneration \\
\hline Gu et al. (201 0) & $\begin{array}{l}\text { Sciatic nerve injury in rats } \\
(1.0 \mathrm{~cm} \text { gap })\end{array}$ & Rat fetal neural stem cells & $\begin{array}{l}\text { Transplanted neural stem cells differentiated } \\
\text { into neurons in peripheral nerves that } \\
\text { synthesize and secreted synaptophysin }\end{array}$ \\
\hline Cheng et al. (2010) & $\begin{array}{l}\text { Sciatic nerve crush injury } \\
\text { in rats }\end{array}$ & $\begin{array}{l}\text { Human amniotic fluid-derived } \\
\text { mesenchymal stem cells and }\end{array}$ & Functional recovery and nerve regeneration \\
\hline Di Summa et al. (2010) & $\begin{array}{l}\text { Sciatic nerve injury in rats } \\
(1.0 \mathrm{~cm} \text { gap })\end{array}$ & $\begin{array}{l}\text { Nerve fibrin conduits seeded with } \\
\text { adipose derived stem cells }\end{array}$ & Enhanced peripheral nerve repair \\
\hline Reid et al. (2011) & $\begin{array}{l}\text { Sciatic nerve in jury in rats } \\
(1.0 \mathrm{~cm} \text { gap })\end{array}$ & Adipose derived stem cells & $\begin{array}{l}\text { Dorsal root ganglia protection from } \\
\text { apoptosis }\end{array}$ \\
\hline
\end{tabular}

Abbreviations: MSC: Mesenchymal stem cell; F1BGFP: Human fibroblast growth factor $1(F G F 1)$ gene 1B promoter ( 540 to +31)-driven green fluorescence; ES: Embryonic stem cell 
ian J Suthar for literature search and manuscript preparation. Lastly, without the unfailing support of Prof. VR Shah in infusing stem cells and the unbiased report of EMG-NCV from Dr. Sanghani, we would not have been able to display the benefits of stem cell therapy.

\section{REFERENCES}

1. Hsu YC, Chen SL, Wang DY, Chiu IM. Stem cell-based therapy in neural repair. Biomed J 2013;36:98-105.

2. Tu YK, Tsai YJ, Chang CH, Su FC, Hsiao CK, Tan JS. Surgical treatment for total root avulsion type brachial plexus injuries by neurotization: A prospective comparison study between total and hemicontralateral C7 nerve root transfer. Microsurgery 2014;34:91-101.

3. Dave SD, Vanikar AV, Trivedi HL. Ex vivo generation of glucose sensitive insulin secreting mesenchymal stem cells derived from human adipose tissue. Indian J Endocrinol Metab 2012;16:65-9.

4. Vanikar AV, Dave SD, Thakkar UG, Trivedi HL. Cotransplantation of adipose tissue-derived insulin-secreting mesenchymal stem cells and hematopoietic stem cells: A novel therapy for insulin-dependent diabetes mellitus. Stem Cells Int 2010;2010:582382.

5. Kim SU, de Vellis J. Stem cell-based cell therapy in neurological diseases: A review. J Neurosci Res 2009;87:2183-200.

6. Marconi S, Castiglione G, Turano E, Bissolotti G, Angiari S, Farinazzo A, et al. Human adipose-derived mesenchymal stem cells systemically injected promotes peripheral nerve regeneration in the mouse model of sciatic crush. Tissue Eng Part A 2012;18:1264-72.
7. Ying $\mathrm{C}, \mathrm{Hu} \mathrm{W}$, Cheng B, Zheng X, Li S. Neural differentiation of rat adipose-derived stem cells in Vitro. Cell Mol Neurobiol 2012;32:1255-63.

8. Ren Z, Wang Y, Peng J, Zhao Q, Lu S. Role of stem cells in the regeneration and repair of peripheral nerves. Rev Neurosci 2012;23:135-43.

9. Xiong Y, Mahmood A, Chopp M. Angiogenesis, neurogenesis and brain recovery of function following injury. Curr Opin Investig Drugs 2010;11:298-308.

10. Chopp M, Li Y, Zhang ZG. Mechanisms underlying improved recovery of neurological function after stroke in the rodent after treatment with neurorestorative cell-based therapies. Stroke 2009;40 (Suppl 3):S143-5.

11. Locatelli F, Bersano A, Ballabio E, Lanfranconi S, Papadimitriou D, Strazzer S, et al. Stem cell therapy in stroke. Cell Mol Life Sci 2009;66:757-2.

12. Bakondi B, Shimada IS, Perry A, Munoz JR, Ylostalo J, Howard AB, et al. CD133 identifies a human bone marrow stem/progenitor cell sub-population with a repertoire of secreted factors that protect against stroke. Mol Ther 2009;17:1938-47.

13. Stroemer P, Patel S, Hope A, Oliveira C, Pollock K, Sinden J. The neural stem cell line CTX0E03 promotes behavioral recovery and endogenous neurogenesis after experimental stroke in a dose-dependent fashion. Neurorehabil Neural Repair 2009;23:895-909.

14. Mehta T, Feroz A, Thakkar U, Vanikar A, Shah V, Trivedi H. Subarachnoid placement of stem cells in neurological disorders. Transplant Proc 2008;40:1145-7. 